\title{
NOTES \\ Oxygen Chemisorption on Supported Gold
}

The absorption of $\mathrm{O}_{2}$ on $\mathrm{Au}$ has been the subject of several investigations, which covered various forms of $\mathrm{Au}$ and widely different experimental conditions. A summary of these studies is reported in Table 1.

From these investigations, the following conclusions emcrge :

1. Despite the diversity in the experimental conditions and the possibility that in some instances physical and not chemical adsorption was observed, there was clear indication that a surface Au-oxygen interaction was present. The lack of detectable adsorption apparent in some cases (4a) was a reflection of the experimental conditions (low virtual oxygen pressure). The degree of surface cleanliness was not always specified in these studies and may have contributed to the different chemisorption behavior recorded.

2. The nature of the adsorption was not definitively established. There remains a controversy over whether oxygen adsorption is endothermic (6) or exothermic ( $\mathscr{E})$.

3. The adsorption stoichiometry was investigated at $120^{\circ} \mathrm{C}$. From measurements on the adsorption rate, it was concluded that at low surface coverage four surface sites per $\mathrm{O}_{2}$ molecules were involved (2). Assuming that $\mathrm{Au}$ atoms are the adsorption sites, a stoichiometry corresponding to $\mathrm{Au}_{2} \mathrm{O}$ was derived. However, as the surface reached saturation, a restructuring of the adsorbate took place and a stoichiometry corresponding to $\mathrm{AuO}$ was found to be more representative of the experimental results.
4. Studies on high area supported Au have not been carried out and it is not known how the effect of Au particle size, support, and preparative conditions influence $\mathrm{O}_{2}$ adsorption.

Earlier investigations on the oxygen transfer reaction between $\mathrm{CO}$ and $\mathrm{CO}_{2}$ showed that some supported Au preparations displayed high catalytic activity at $350^{\circ} \mathrm{C}(8)$. More recent studies on the reduction of $\mathrm{NO}$ by $\mathrm{H}_{2}$ catalyzed by supported $\mathrm{Au}$ indicated a range of the reaction selectivity to $\mathrm{N}_{2}$ from 4 to $90 \%$ at $350^{\circ} \mathrm{C}$ (9). It was suggested that the effect was a consequence of an interaction between the Au particles and the support.

In view of the complex behavior of massive $A u$ and the lack of information on supported $\mathrm{Au}$ in oxygen chemisorption and of the ready activity of supported Au in cataly tic reactions involving oxygen bearing molecules, it secmed interesting to investigate the adsorption of molecular oxygen on supported $\mathrm{Au}$. Such a study, in addition to providing confirmation of some of the patterns discovered at surfaces of massive $\mathrm{Au}$, would be helpful in assessing the potential of oxygen adsorption as a characterization method for the size of the supported Au particles.

Following these considerations we have conducted a series of measurements on the adsorption of $\mathrm{Au}$ supported on $\mathrm{MgO}$, $\mathrm{SiO}_{2}$, and $\mathrm{Al}_{2} \mathrm{O}_{3}$ in the temperature range 170 to $450^{\circ} \mathrm{C}$ and partial pressures of 
TABLE 1

Oxygen Adsorption on $\mathrm{Au}$

\begin{tabular}{|c|c|c|c|c|}
\hline Type of Au & $\begin{array}{l}\text { Pressure of } \mathrm{O}_{2} \\
\quad \text { (Torr) }\end{array}$ & $\begin{array}{l}\text { Temperature } \\
\left({ }^{\circ} \mathrm{C}\right)\end{array}$ & Characteristic behavior & Ref. \\
\hline Powder & 100 to 760 & 98 to 157 & Amount adsorbed increasing with temperature & $(1)$ \\
\hline Powder & 0.2 & 120 & $\begin{array}{l}\text { Adsorption heat decreasing with increasing } \\
\text { surface coverage }\end{array}$ & (2) \\
\hline Powder & 1 & -89 to 450 & Isobar shows maxima at $-50,210^{\circ} \mathrm{C}$ & (3) \\
\hline Powder & $3 \times 10^{6} a$ & 295 to 380 & No detectable adsorption & $(4 a)$ \\
\hline Wire & 0.2 & 50 to 400 & Bulk incorporation at $T>200^{\circ} \mathrm{C}$ & (5) \\
\hline Foil & $10^{-7}$ & 25 to 700 & $\begin{array}{l}\text { Low surface coverage; isobar shows maximum } \\
\text { at } 427^{\circ} \mathrm{C}\end{array}$ & (6) \\
\hline Film & $10^{-2}$ & 25 to 405 & Irreversible chemisorption; no incorporation & $(7)$ \\
\hline Film & $10^{-3}$ to $10^{-2}$ & -183 to $0^{\circ} \mathrm{C}$ & Physical adsorption; no chemisorption & $(4 b)$ \\
\hline
\end{tabular}

${ }^{a} \mathrm{p}_{\mathrm{H}_{2}} \mathrm{O} / \mathrm{p}_{\mathrm{H}_{2}}$.

$\mathrm{O}_{2}$ in the range of 0.4 to 6.0 Torr ( 1 used were: $\mathrm{SiO}_{2}\left(400 \mathrm{~m}_{2} / \mathrm{g}\right), \mathrm{Al}_{2} \mathrm{O}_{3}$ (180 Torr $=133.33 \mathrm{~N} \mathrm{~m}^{-2}$ ).

\section{EXPERIMENTAL}

Materials. Reagent grade $\mathrm{HAuCl}_{4}$, $\mathrm{KAu}(\mathrm{CN})_{2}$, and $\mathrm{Au}(\mathrm{en})_{2} \mathrm{Cl}_{3}(10)$, were used as precursor salts. Ultra high purity $\mathrm{H}_{2}$ and $\mathrm{O}_{2}(>99.995 \%)$ were employed. Supports $\left.\mathrm{m}^{2} / \mathrm{g}\right)$, and $\mathrm{MgO}\left(12 \mathrm{~m}^{2} / \mathrm{g}\right)$. Preparative procedures, composition and thermal treatments prior to adsorption are summarized in Table 2. Au preparations were characterized by wide-angle X-ray scattering (WAXS) and transmission electron microscopy (TEM). WAXS determinations were

TABLE 2

Supported Au: Composition, Preparation, and Adsorption Pretreatment

\begin{tabular}{|c|c|c|c|}
\hline Support & $\begin{array}{c}\mathrm{Au}^{a} \\
(\mathrm{wt} \%)\end{array}$ & Preparative method & Adsorption pretreatment \\
\hline $\mathrm{SiO}_{2}$ & 0.54 & $\begin{array}{l}\text { Impregnation with } \mathrm{HAuCl}_{4} \text {, } \\
\mathrm{H}_{2} \text { reduction, } 400^{\circ} \mathrm{C}, 2 \mathrm{hr}\end{array}$ & $\begin{array}{r}300^{\circ} \mathrm{C}, 1 \mathrm{hr} \text {, in air, } 70 \text { Torr } \\
400^{\circ} \mathrm{C}, 1 \mathrm{hr} \text {, in } \mathrm{H}_{2}, 70 \mathrm{Torr} \\
\text { evacuated at } 450^{\circ} \mathrm{C}, 30 \mathrm{~min}\end{array}$ \\
\hline $\mathrm{SiO}_{2}$ & 1.24 & $\begin{array}{l}\text { Cationic exchange with } \\
\mathrm{Au}(\mathrm{en})_{2} \mathrm{Cl}_{3}, \mathrm{H}_{2} \text { reduction, } \\
1 \mathrm{~atm}, 400^{\circ} \mathrm{C}, 2 \mathrm{hr}\end{array}$ & Same \\
\hline $\mathrm{SiO}_{2}$ & 1.30 & Same as $1.24 \mathrm{wt} \%$ & Same \\
\hline $\mathrm{SiO}_{2}$ & 3.11 & $\begin{array}{l}\text { Impregnation with } \mathrm{KAu}(\mathrm{CN})_{2} \\
350^{\circ} \mathrm{C}, 2 \mathrm{hr}, 0.1 \text { Torr }\end{array}$ & Same \\
\hline $\mathrm{MgO}$ & 2.00 & $\begin{array}{l}\text { Impregnation with } \mathrm{HAuCl}_{4} \text {, } \\
\text { reduction with oxalic acid, } \\
350^{\circ} \mathrm{C}, 2 \mathrm{hr}, 0.1 \text { Torr }\end{array}$ & $\begin{array}{l}10^{-4} \text { Torr, } 350^{\circ} \mathrm{C}, 8 \mathrm{hr} \\
\text { cooled to } 300^{\circ} \mathrm{C}\end{array}$ \\
\hline $\mathrm{MgO}$ & 3.46 & $\begin{array}{l}\text { Impregnation with } \mathrm{HAuCl}_{4} \text {, } \\
\text { reduction with } \mathrm{H}_{2}, 1 \mathrm{~atm}, \\
2 \mathrm{hr}, 300^{\circ} \mathrm{C} ; 2 \mathrm{hr}, 400^{\circ} \mathrm{C}\end{array}$ & Same as $\mathrm{Au} / \mathrm{SiO}_{2}$ \\
\hline $\mathrm{Al}_{2} \mathrm{O}_{3}$ & 4.25 & $\begin{array}{l}\text { Impregnation with } \mathrm{KAu}(\mathrm{CN})_{2} \\
350^{\circ} \mathrm{C}, 2 \mathrm{hr}, 0.1 \text { Torr }\end{array}$ & Same as $\mathrm{Au} / \mathrm{SiO}_{2}$ \\
\hline
\end{tabular}

\footnotetext{
${ }^{a}$ By atomic absorption and neutron activation.
} 


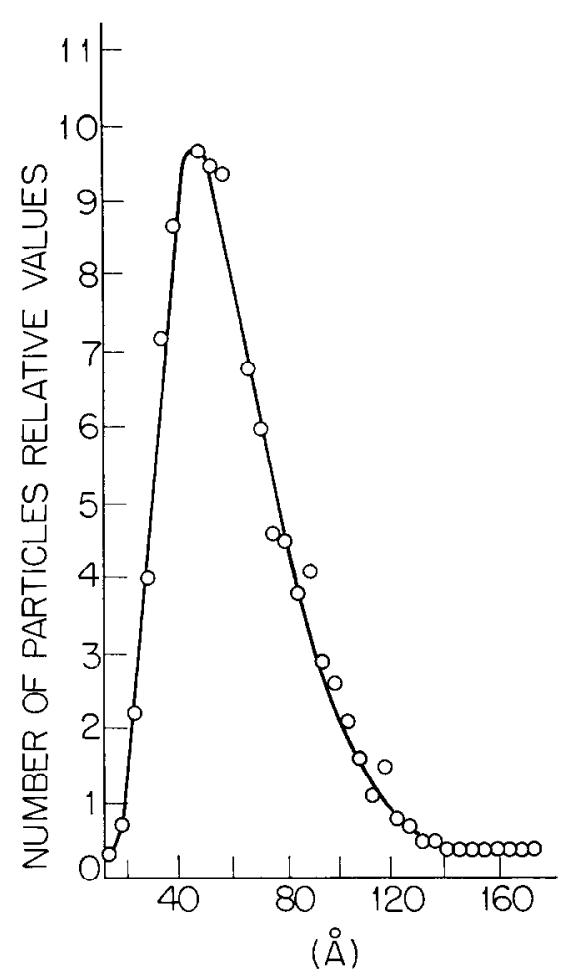

FIG. 1. Size distribution of supported Au particles in 1.24 wt $\%$ Au- $\mathrm{SiO}_{2}$ by Transmission Electron Microscopy.

carried out in an X-ray diffractometer, having a resolution of $0.005^{\circ}$. The crystallite size, $d$, was calculated by means of the Scherrer expression after correction for the instrument contribution (11), $d=90 \lambda / \pi B_{\frac{1}{2}}$ $\cos \theta[\AA]$. (12), where $\lambda$ is the CuK $K \alpha$ wavelength, $\theta$ the diffraction angle, and $B_{\frac{1}{2}}$ the width of half the height of the diffraction peak, usually those from the (200) planes. Electron microscopy size measurements were conducted in a high-resolution transmission Siemens Elmiskop Electron Microscope. Catalyst samples for the microscope were ground in a mullite mortar and pestle; the fine powder was sprinkled onto a dry prepared parlodion substrate on microscope grids. The film was then placed in a vacuum evaporator and coated with about $100 \AA$ of evaporated carbon. The sample grids were then placed on adsorbing paper soaked in amylacetate to dissolve the parlodion film prior to examination. Magnification was calibrated using the (002) planes of graphitized carbon black. Measurements of $\mathrm{Au}$ particle sizes and size distribution were made with micrometer eyepiece from enlarged prints. Size distributions had the typical skewed shape (Fig. 1). Oxygen adsorption was measured in a conventional, all glass, volumetric system with a Televac thermocouple manometer calibrated on oxygen gas. Linear adsorption isotherms were found on the pure supports; upon extrapolation to zero pressure, there was no evidence of chemisorption. Therefore no correction for support was necessary when calculating the amount chemisorbed on the supported Au. The accuracy of the adsorption technique was estimated at $\pm 0.1 \mu \mathrm{mole} / \mathrm{g}$ sample. Particle diameter from oxygen adsorption was calculated using the relation $d=6 / S \rho$, where $S$ is the surface area and $\rho$ the density.

\section{RESULTS}

Since preliminary runs indicated that no detectable adsorption took place on each sample investigated at temperatures $<170^{\circ} \mathrm{C}$ (in the course of $24 \mathrm{hr}$ of observation), all subsequent measurements were carricd out at tempcratures $>170^{\circ} \mathrm{C}$. Typical results for $\mathrm{SiO}_{2}$ supported $\mathrm{Au}$ are reported in Fig. 2 for various initial $\mathrm{O}_{2}$ partial pressures. In all instances, the adsorption showed a fast, initial period followed by one of slcw or negligible adsorption. At $200^{\circ} \mathrm{C}$ and in the lower range of $\mathrm{O}_{2}$ pressures (2.94 Torr), initial rapid adsorption led to surface saturation and no further adsorption could be detected even after long periods of time. At higher $\mathrm{O}_{2}$ pressures (4.78 and 5.19 Torr) rapid adsorption was followed by a much slower, but casily detectable, adsorption. After $2 \mathrm{hr}$ at $200^{\circ} \mathrm{C}$, an additional $50 \%$ pressure decrease was observed with no indication of a ready saturation. It was assumed that the first rapid process was an indication of 
monolayer chemisorption, while the second one corresponded to diffusion onto the ceramic support. By extrapolation to zero time of the lincar portion of the isotherms, the oxygen uptake corresponding to the fast initial period was calculated. A typical plot of the oxygen uptake versus $P_{\mathrm{O}_{2}}$ is reported in Fig. 3 as a function of $\mathrm{P}_{\mathrm{O}_{2}}$ for $1.24 \mathrm{wt} \% \mathrm{Au}-\mathrm{SiO}_{2}$. By means of the values of the saturation $\mathrm{O}_{2}$ uptake, calculated with the aid of the above procedure, the average diameter of the Au particles was computed and it is reported in Table 3, together with the results of size measurements from WAXS and TEM. In these calculations an atomic surface density in polycrystalline Au of $1.15 \times 10^{15}$ atoms $/ \mathrm{cm}^{2}$ was employed, and the assumption of a spherical particle shape was used. Inspection of Table 3 shows that for adsorption at $200^{\circ} \mathrm{C}$ the $\mathrm{Au} / \mathrm{O}=2$ stoichiometry yields results more consistent with particle size calculated from WAXS and TEM. As mentioned previously, the $\mathrm{Au} / \mathrm{O}=2$ stoichiometry was also found in earlier investigations to better represent the adsorption on unsupported Au powder (2). Upon increasing the temperature of adsorption on supported $\mathrm{Au}$ to $300^{\circ} \mathrm{C}$, the $\mathrm{Au} / \mathrm{O}=1$ stoichiometric ratio gave results more consistent with the WAXS and TEM size calculations.

The agreement between size measurements from WAXS, TEM, and $\mathrm{O}_{2}$ adsorption is considered satisfactory, since the highest discrepancy between them is by a factor of 1.5. The only exception is 4.25 wt $\% \mathrm{Au}-\mathrm{Al}_{2} \mathrm{O}_{3}$, which shows a discrepancy by a factor of 4.2. The techniques employed in this study for particle size determination involve several assumptions. Furthermore, some supported Au samples were found to display a complex morphological and chemical behavior (13), including the simultaneous presence of a dispersed phase of widely different ranges of particle sizes (from $>30$ to $>2000 \AA$ ) and a "dissolved" phase in which single atoms or two-dimen-

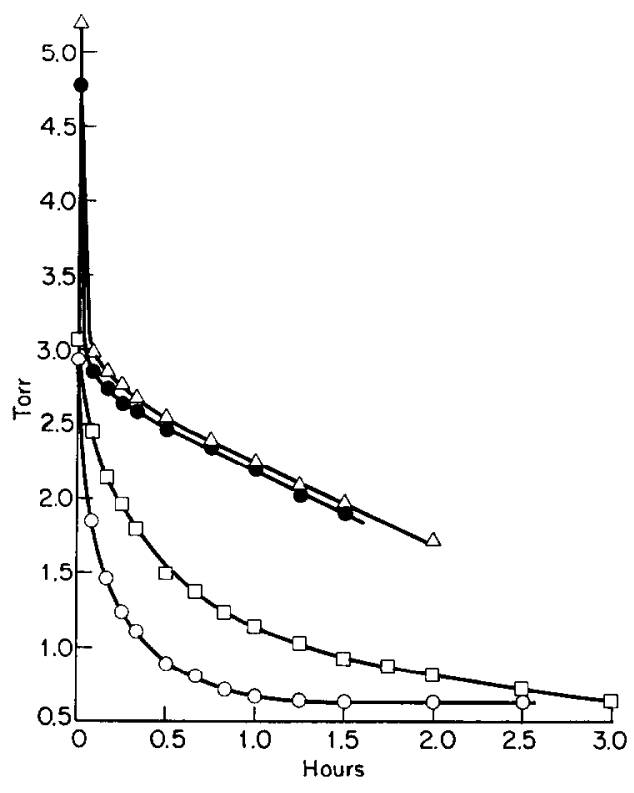

Fig. 2. Adsorption of $\mathrm{O}_{2}$ on 1.24 wt $\% \mathrm{Au}-\mathrm{SiO}_{2}$, $200^{\circ} \mathrm{C} ; \mathrm{O}, p_{\mathrm{O}_{2}}, 2.94$ Torr; $, P_{\mathrm{O}_{3}}, 4.78$ Torr $;, P_{\mathrm{O}_{2}}$, 5.19 Torr; $\square, 1.30$ wt $\% \mathrm{Au}-\mathrm{SiO}_{2}, 170^{\circ} \mathrm{C}, P_{\mathrm{O}_{2}}$, 3.1 Torr.

sional "rafts" of a few atoms are imbedded in the support. Since in these cases $\mathrm{O}_{2}$ chemisorption indicates an average value of particle size that would not represent realistically the state of the $\mathrm{Au}$, a direct comparison between Au prticle size derived from oxygen chemisorption with that from WAXS and TEM would be difficult to justify.

From the results reported in the literature (Table 1) the impression is generated that the heat of $\mathrm{O}_{2}$ adsorption on $\mathrm{Au}$ may vary between wide limits. If the adsorption

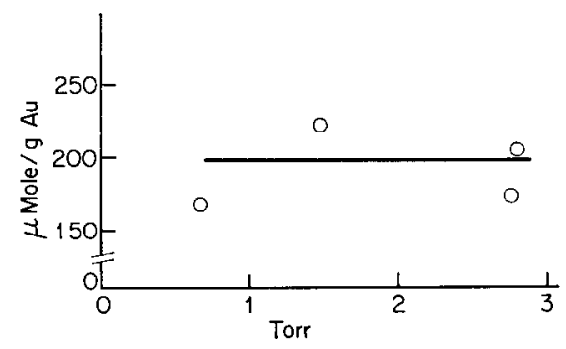

FIG. 3. Oxygen uptake versus $p_{0_{2}}$, on $1.24 \mathrm{wt} \%$ $\mathrm{Au}-\mathrm{SiO}_{2}, 200^{\circ} \mathrm{C}$. 
TABLE 3

Diameter of Supported Au Particles

\begin{tabular}{|c|c|c|c|c|c|}
\hline \multirow{3}{*}{$\begin{array}{c}\text { Sample } \\
\text { composition } \\
(\text { wt } \%)\end{array}$} & \multirow[t]{3}{*}{$\begin{array}{c}\text { Temperature } \\
\left({ }^{\circ} \mathrm{C}\right)\end{array}$} & \multicolumn{4}{|c|}{$\begin{array}{l}\text { Au particle diametcr } \\
(\AA)\end{array}$} \\
\hline & & \multicolumn{2}{|c|}{$\mathrm{O}_{2} \mathrm{ads}$} & \multirow[t]{2}{*}{ TEM } & \multirow[t]{2}{*}{$\mathrm{W} \Lambda \mathrm{XS}$} \\
\hline & & $\frac{A u}{O}=1$ & $\frac{\mathrm{Au}}{\mathrm{O}}=2$ & & \\
\hline $0.54 \mathrm{Au}-\mathrm{SiO}_{2}$ & 200 & 1340 & 670 & - & 450 \\
\hline \multirow{4}{*}{$1.24 \mathrm{Au}-\mathrm{SiO}_{2}$} & $\begin{array}{l}300 \\
200\end{array}$ & $\begin{array}{l}500 \\
176\end{array}$ & $\begin{array}{r}230 \\
88\end{array}$ & \multirow{4}{*}{60} & \multirow{4}{*}{40} \\
\hline & 200 & 122 & 61 & & \\
\hline & 200 & 172 & 86 & & \\
\hline & 200 & 144 & 72 & & \\
\hline \multirow{2}{*}{$1.30 \mathrm{Au}-\mathrm{SiO}_{2}$} & 200 & 118 & 59 & \multirow{2}{*}{85} & \multirow{2}{*}{ - } \\
\hline & 170 & 144 & 72 & & \\
\hline $3.11 \mathrm{Au}-\mathrm{SiO}_{2}$ & 200 & 2600 & 1300 & - & 900 \\
\hline \multirow[t]{2}{*}{$2.0 \mathrm{Au}-\mathrm{MgO}$} & 200 & 84 & 42 & \multirow{2}{*}{80} & \multirow{2}{*}{55} \\
\hline & 300 & 72 & 36 & & \\
\hline $3.46 \mathrm{Au}-\mathrm{MggO}$ & 200 & 174 & 87 & 83 & - \\
\hline $4.25 \mathrm{Au}-\mathrm{Al}_{2} \mathrm{O}_{3}$ & 200 & 1280 & 640 & 220 & 150 \\
\hline
\end{tabular}

${ }^{a} \pm 10 \% \mathrm{O}_{2}$ adsorption, $\pm 20 \%$ TEM, WAXS.

heat is impurity controlled, it should be quite temperature dependent. To assess the extent of irreversibly adsorbed versus reversibly adsorbed oxygen, adsorptiondesorption experiments were carried out on $2.0 \mathrm{wt} \% \mathrm{Au}-\mathrm{MgO}$. It was found that at $200^{\circ} \mathrm{C}$ all of the $\mathrm{O}_{2}$ was irreversibly adsorbed, while at $400^{\circ} \mathrm{C}$ all of the $\mathrm{O}_{2}$ could be desorbed. This is reminiscent of earlier investigations on unsupported $\mathrm{Au}$ powder showing that $\mathrm{O}_{2}$ chemisorbed at $130^{\circ} \mathrm{C}$

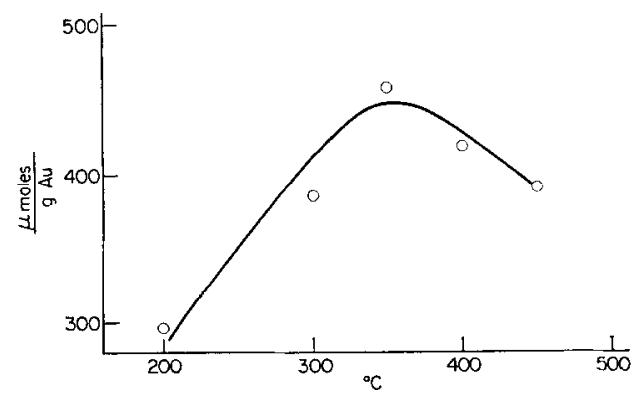

FIG. 4. $\mathrm{O}_{2}$ adsorption isobar for $2 \mathrm{wt} \% \mathrm{Au}-\mathrm{MgO}$ as a function of temperature; $p_{\mathrm{O}_{2}}, 27$ Torr. could not be desorbed at the same temperature; rather reacting it with $\mathrm{H}_{2}$ was necessary to free the surface (1). On Au films at temperatures as high as $405^{\circ} \mathrm{C}$, the adsorption of $\mathrm{O}_{2}$ was found to be irreversible ( 7$)$. The adsorption isobar showed a maximum (Fig. 4) at about $340^{\circ} \mathrm{C}$. Variation in surface stoichiometry and/or endothermic dissolution of oxygen, as discussed above, may be postulated to explain the observed maximum but, clearly, other explanations may be suggested. More extended investigations of the effect are necessary for its definition. Earlier, a maximum was observed at $210^{\circ} \mathrm{C}$ in the $\mathrm{O}_{2}$ adsorption on $\mathrm{Au}$ powder (3). Our results are more consistent with the maximum at $427^{\circ} \mathrm{C}$ obtained on unsupported $\mathrm{Au}$ powder $(6)$ and we concur with these authors that endothermic adsorption may be a determining factor in the maximum and a fundamental link between supported and nonsupported Au surfaces. 


\section{CONCLUSIONS}

The adsorption of oxygen at $200^{\circ} \mathrm{C}$ and initial oxygen pressure of 3 to 6 Torr is a suitable method to assess the surface area of supported $\mathrm{Au}$. Under these conditions the correct stoichiometry corresponds to $\mathrm{Au} / \mathrm{O}=2$. There are indications that the extent and strength of the adsorption are sensitive to surface contamination of the $\mathrm{Au}$. As the temperature is increased from 200 to $400^{\circ} \mathrm{C}$, the adsorption becomes reversible, while the isobar shows a maximum at $340^{\circ} \mathrm{C}$. These effects are qualitatively consistent with the adsorption behavior recorded at surfaces of massive $\mathrm{Au}$.

\section{ACKNOWLEDGMENT}

We wish to express our apprecialion to Dr. V. Mormino for the results on $\mathrm{Au}-\mathrm{MgO}$. The work was carried out with the financial support of the National Science Foundation Grant Eng 75-14193 and Montedison S.P.A. This support is gratefully acknowledged.

\section{REFERENCES}

1. Benton, A. F., and Elgin, J. L., J. Amer. Chem. Soc. 49, 2426 (1927).

2. Dobrovol'skii, N. N., Ostrovskii, V. E., Rabashov, A. M., and Temkin, M. I., Dokl. Akad. Nauk SSSR, 183, No. 5, 1120 (1968).

3. MeDonald, W. R., and Hayes, K. E., J. Calal. 18, 115 (1970).

4. (a) Gonzalez, O. D., and Parravano, G., J. Amer.
Chem. Soc. 78, 4533 (1956); (b) Trapnell, B. M. W., Proc. Roy. Soc. A 218, 566 (1953).

5. Kulkova, N. P., and Leveshenko, L. P., Kinet. Catal. 6, 688 (1965).

6. Endow, N., Wood, B. J., and Wise, H., J. Calal. 15, 316 (1969).

7. Richardson, P. C., and Rossington, D. R., $J$. Catal. 20, 420 (1971).

8. Cha, D. Y., and Parravano, G., J. Catal. 18, 200 (1970).

9. Galvagno, S., and Parravano, G., J. Catal. 55, 178 (1978).

10. Block, B. P., and Bailar, J. C., Jr., J. Amer. Chem. Soc. 73, 4722 (1951).

11. Lipson, H., and Steeple, H., "Interpretation of X-Ray Powder Diffraction Patterns." St. Martin's Press, New York, 1970.

12. Neff, H., "Grundl. Anwendung der Rontgenfeinstrukturanalyse," Oldenbourg, München, 1962.

13. Bassi, I. W., Lytle, F. W., and Parravano, G., J. Catal. 42, 139, (1976); Cocco, G., et al., unpublished results.

\section{T. Funushima \\ S. Galvagno ${ }^{1,2}$ \\ G. Parravano ${ }^{3}$}

Department of Chemical Engineering

The University of Michigan

Ann Arbor, Michigan 48109

\section{Received February 17, 1978}

${ }^{1}$ On leave from Montedison S.P.A., Novara, Italy.

2 To whom inquiries about this note should be addressed.

${ }^{3}$ Deceased on April 1, 1978. 